\title{
Antioxidant Activity and Lipoxygenase Enzyme Inhibition As- say with Total Flavonoid Assay of Garcinia porrecta Laness. Stem Bark Extracts
}

\author{
Amalia Cipta Sari, Berna Elya*, Katrin
}

\section{Amalia Cipta Sari, Berna Elya*, Katrin \\ Department of Pharmacognosy- Phytochemistry, Faculty of Pharmacy, Universitas Indonesia, Kampus Baru UI Depok, 16424, Depok, INDONESIA.}

\section{Correspondence \\ Berna Elya \\ Faculty of Pharmacy, Universitas Indone- sia, Gedung A Rumpun IImu Kesehatan Lantai 1, Kampus UI, Depok, Jawa Barat - 16424, INDONESIA. \\ Phone: +62 217270031 \\ E-mail: berna.elya@gmail.com}

\section{History}

- Submission Date: 21-12-2016;

- Review completed: 05-01-2017;

- Accepted Date: 16-01-2017.

DOI : 10.5530/pj.2017.2.44

Article Available online http://www.phcogj.com/v9/i2s

\section{Copyright}

(C) 2017 Phcog.Net. This is an openaccess article distributed under the terms of the Creative Commons Attribution 4.0 International license.

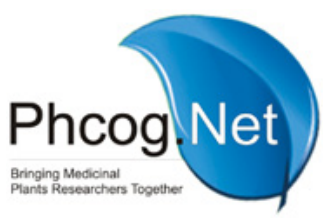

\begin{abstract}
Introduction: The genus Garcinia which is rich of secondary metabolites, mainly flavonoids, have known to have antioxidant and anti-inflammatory activity through the inhibition of lipoxygenase. There isn't found literature indicating research on inhibition of lipoxygenase activity been done in this plant. The purpose of this study is to obtain the data and determine the potential antioxidant activity, and inhibition of lipoxygenase activity of Garcinia porrecta Laness. stem bark extracts. Methods: This research is included FRAP (Ferric Reducing Antioxidant Power) method antioxidant assay, in vitro lipoxygenase inhibition assay, flavonoids qualitative analysis by thin layer chromatography, and total flavonoids assay in the most active extract. Results: The results showed the methanol, ethyl acetate and n-hexane extracts of G. porrecta Laness. stem bark using FRAP method, has antioxidant activity with EC50 values respectively 1.33; 4.97; and $19.96 \mu \mathrm{g} / \mathrm{mL}$ and lipoxygenase inhibition activity with IC50 values $0.23 ; 0.52$; and $4.87 \mu \mathrm{g} / \mathrm{mL}$. The most active extract in the both assay is methanol extract which has total flavonoids of $5.66 \mathrm{mg} \mathrm{OE} / \mathrm{g}$ (quercetin equivalent). Conclusion: The results from the study show extracts of the stem bark of $G$. porrecta Laness. has antioxidant activity and potential for lipoxygenase inhibition.
\end{abstract}

Key words: Antioxidant, Flavonoid, FRAP, Garcinia porrecta Laness, Lipoxygenase.

\section{INTRODUCTION}

Free radicals are atoms or molecules that are unstable (one electron or more without a partner), so as to obtain an electron pair, free radicals tend to look for other molecules and atoms of lead compounds that are not normal and starts a chain reaction in the body. ${ }^{1}$ One example of the kind of free radicals in the body is a reactive oxygen species (ROS) and reactive nitrogen species (RNS, such as nitric oxide, NO ) generated by the enzyme NO synthase (NOS) and NAD (P) H oxidase isoform. The beneficial effects of ROS / RNS (eg superoxide radicals and nitric oxide) occurs at concentrations of low/moderate and involves a physiological role in the cellular response to noxia, such as in the defense against infectious agents, in function of a number of cellular signaling pathways, and the induction of mitogenic response, Excess production of ROS (arising either from mitochondrial electron transport chain or excessive stimulation of NAD $(\mathrm{P})$ $\mathrm{H})$ produces oxidative stress, a process that became the mediator of the damage to cell structures, including lipids in cell membranes, proteins, and DNA. As a result of oxidative stress that accumulates can lead to degenerative diseases such as Alzheimer's, cancer and body triggers cell death (apoptosis) faster. ${ }^{2}$ One way to deal with free radicals is with antioxidants. Antioxidants are compounds that can slow or prevent damage caused by free radicals by dampening the activity of free radicals or break the chain reaction of oxidation caused by free radicals. ${ }^{3}$
One of the effects of free radicals is the process of induction of cytokines, inflammatory mediators in the body, which causes an inflammatory response occurs. ${ }^{4}$ Inflammation is a protective response the body's normal when there is tissue injury which involves a variety of physiological processes in the body such as the activation of the enzyme inflammatory, inflammatory mediator release, the movement of white blood cells through the capillaries into areas of inflammation, cell migration, and the restoration of damaged tissue. ${ }^{5}$ Lipoxygenase (LOX) is one enzyme that has a role in inflammation, especially in the biochemical processes of leukotrienes. Leukotrienes are the main regulator of allergic reactions and inflammation. Currently, lipoxygenase inhibitors become a potentially important agent that shows significant anti-inflammatory activity. ${ }^{6,7}$ Flavonoids like baicalein and apigenin have been known to be useful as inhibitors of lipoxygenase in vitro. ${ }^{8}$

Garcinia is the largest genus of the family Clusiaceae which has about 400 species is widespread in Asia, Africa, South America, and the Polynesian Islands. Garcinia contains many secondary metabolites, mainly triterpenes, flavonoids, xanthones, and phloroglucinol that have pharmacological activities such as anticancer, anti-inflammatory, antibacterial, antiviral, anti-HIV, antidepressants, and antioxidants. ${ }^{9}$ One species that grows in Indonesia Garcinia, Garcinia porrecta Laness at which previous studies have shown that stem bark of the plant contains several kinds of compounds such as porsanton and dulsisan- 
ton which is a compound class and compounds porlanosterol xanthones. Testing the antioxidant activity in extracts of $G$. porrecta Laness. already been done by the DPPH (2,2-diphenyl-1-picrylhydrazyl) radical scavenger which showed significant antioxidant activity $\left(\mathrm{IC}_{50}<50 \mu \mathrm{g} \mathrm{mL}{ }^{-1}{ }^{10}{ }^{10}\right.$ Until now, this has never been tested inhibition of lipoxygenase enzyme activity and antioxidant activity test, especially with methods FRAP (Ferric Reducing Antioxidant Power) of the plant G. porrecta Laness.

It encourages the study of the antioxidant activity of G. porrecta Laness. stem bark extracts in vitro with FRAP method and on the inhibition of lipoxygenase enzyme activity which is one of the inflammatory factors. Extracts with antioxidant activity and inhibition of lipoxygenase and analyzed the content of flavonoids qualitatively by thin layer chromatography. Extract the most active in the antioxidant activity and inhibition of lipoxygenase assay will be set on total flavonoids assay with $\mathrm{AlCl}_{3}$ quantitative method.

\section{MATERIALS AND METHOD}

\section{Chemicals}

The materials used in this research is distilled water, demineralised water, ethanol pro analysis (Merck), methanol pro analysis (Merck), ethyl acetate (Merck), n-hexane (Merck), dichlormethane, acetone, toluene, formic acid, enzymes lipoxygenase from soybeans (Sigma-Aldrich L37935), linoleic acid (Sigma-Aldrich), boric acid (Merck), sodium hydroxide (Mallinckrodt), sodium acetate, TPTZ (2,4,6-tripyridyl-s-triazine) (Sigma-Aldrich), iron (III) chloride (Merck), hydrochloric acid (Merck), glacial acetic acid, aluminum (III ) chloride, and sodium acetate.

\section{Material Comparative}

Baicalein (Sigma-Aldrich) as a positive control of the test the antioxidant activity with FRAP and test methods lipoxygenase inhibition activity. Quercetin (Sigma-Aldrich) as a positive control on a thin layer chromatography and the assay methods flavonoids $\mathrm{AlCl}_{3}$.

\section{Equipment}

Equipment used in this research include an analytical balance (Sartorius 7), digital scales (ACIS, Japan), vortex mixer (Wisemix), $\mathrm{pH}$ meter (Eutech Instruments, France), refrigerator (Sharp), freezer (Sharp), a water bath (Imperial IV Water Bath Lab-Line), condenser, 10-100 mL micropipette (Corning), 100-1000 mL micropipette (Finpipette), incubator (Gemmyco), sonicator (Wiseclean), UV-Vis spectrophotometer (PG instruments Ltd. T80), quartz cuvette (Merck, Germany), chamber, room thermometer, test tube rack and glass tools used in laboratories in general.

\section{Work Stages}

Stages of the work done in this study started with the preparation of the methanol extract, ethyl acetate and n-hexane bark of Garcinia porrecta Laness., the antioxidant activity FRAP method and the inhibitory activity of lipoxygenase done on the third step in order to obtain an extract that has the highest activity. The extract containing flavonoids will be assayed quantitatively by the method of $\mathrm{AlCl}_{3}$.

\section{Antioxidant Activity Test FRAP Ferric Reducing Antioxidant Power) Method}

FRAP method procedure of antioxidant activity assay is in Table 1. Having obtained the data, calculated the percentage of capacity reduction of Fe ions ${ }^{3+}$ by the positive control baicalein/extract the FRAP solution. The percentage of capacity can be calculated using the formula

$\%$ Capacity $=(1-\mathrm{Ts}) \times 100 \%$
Ts $=$ Transmittan

As $=-\log \mathrm{Ts}$

As = Absorbance positive control/extract - The absorbance of the solution FRAP

$\mathrm{EC}_{50}$ of samples was calculated using the equation of nonlinear regression with aid analysis software GraphPad PRISM ${ }^{\circledR}$ version 7, the concentration of the sample is transformed into a logarithm as the $\mathrm{X}$-axis and $\mathrm{y}$-axis percent capacity.

\section{Lipoxygenase Inhibition Activity Test}

Optimization tests were done prior the sample test. Each procedure is described in Table 2 through 5. Optimization of Enzyme concentration was described in Table 11 . Inhibition of lipoxygenase activity by the extract of methanol, ethyl acetate, n-hexane Garcinia porrecta Laness. stem bark and baicalein (Table 6) can be known from the value of \% inhibition calculated using the following equation.

$\%$ inhibition of lipoxygenase $=\frac{(A-B)-(C-D)}{(A-B)} \times 100 \%$

Note:

A = Absorbance reference solution with enzyme

$\mathrm{B}=$ Absorbance reference solution without enzymes

$\mathrm{C}=$ Absorbance sample solution with the enzyme

$\mathrm{D}=$ Absorbance of the sample solution without enzymes

Value $\mathrm{IC}_{50}$ samples were determined by the equation of nonlinear regression with the help of analysis software GraphPad Prism version 7, the $\mathrm{x}$-axis shows the concentration of the sample that has been transformed into a logarithm and the y-axis shows the \% inhibition.

\section{Determination of Total Flavonoids with Colorimetric Method of AlCl3 to Quercetin and G. porrecta Laness. Stem Bark Extract}

The test procedure involves reacting methanol extract at a concentration of $6000 \mathrm{mg} / \mathrm{mL} 0.5 \mathrm{ml}$, then added $1.5 \mathrm{~mL}$ of methanol, $0.1 \mathrm{ml}$ of a solution of $\mathrm{AlCl}_{3}$ a $10 \% 0.1 \mathrm{ml}$, and $2.8 \mathrm{ml}$ aquadest. The mixture was incubated for $30 \mathrm{~min}$ at room temperature. Uptake is measured using UV-VIS spectrophotometry at a wavelength of $435 \mathrm{~nm}$. Quercetin was used as a positive control and treated similarly to extract and quercetin calibration curves made with varying concentrations. The linear regression equation quercetin produced can be used to calculate the concentration of flavonoids contained in the sample. Controls for quercetin and extracts made by replacing the solution of $\mathrm{AlCl}_{3} 10 \%$ with distilled water and treated the same as quercetin and samples. If needed all the prepared solution was filtered with filter paper before measuring absorbance. Levels of flavonoids total calculated in quercetin equivalent $(\mathrm{QE})$, with the formula:

\section{RESULTS AND DISCUSSION}

\section{Test Antioxidant Activity Method FRAP}

Based on testing FRAP, extracts methanol, ethyl acetate, and n-hexane G. porrecta Laness. stem bark shows the same thing with baicalein of increased extract concentrations proportional to the increase in antioxidant capacity. Data Values of $\mathrm{EC}_{50}$ tests of antioxidant activity methods FRAP was described in Table 7. Meanwhile, data values of $\mathrm{EC}_{50} \mathrm{n}$ hexane, ethyl acetate and methanol extract tests of antioxidant activity methods FRAP was described in Table 8-10. When compared with the antioxidant capacity baicalein reaching $50 \%$ at a concentration of 1.16 
$\mathrm{mg} / \mathrm{mL}$, then either extract methanol, ethyl acetate and n-hexane from the G. porrecta Laness. stem bark showed lower antioxidant activity with FRAP method. Based on the classification, ${ }^{11}$ the methanol extract, ethyl acetate and $n$-hexane is classified as a very powerful antioxidant.

The antioxidant activity could have been influenced by the presence of hydroxyl groups, such as those found in the phenolic compounds, flavonoids, and tannins. The antioxidant activity depends on the number and position of hydroxyl contained in the compound. ${ }^{12}$ The antioxidant activity of the extracts of methanol and ethyl acetate allegedly influenced by the presence of flavonoids compounds in both the extract. The content of flavonoids in the extract will be analyzed further using thin layer chromatography. Flavonoids in the extract are expected to be a reductant/electron donor from the $-\mathrm{OH}$ group at his disposal to reduce the Feions $^{3+}$ to $\mathrm{Fe} 2+$.

In the n-hexane extract, antioxidant activity is also quite active although it is lower than both the other extracts. The antioxidant activity of nhexane extracts suspected because of the non-polar compounds such as terpenoids interested in the n-hexane extract of G. porrecta Laness. stem bark.

\section{Lipoxygenase Inhibition Activity Test}

\section{Inhibition of Lipoxygenase Activity of Baicalein Positive Control}

Based on the previous testing, known baicalein have $\mathrm{IC}_{50}$ values of 0.0012 $\mathrm{mM}(0.32 \mathrm{mg} / \mathrm{mL})^{13}$ as a competitive inhibitor of linoleic acid and 22.5 $\mu \mathrm{M}(6.08 \mathrm{mcg} / \mathrm{mL})$ as a lipoxygenase inhibitor in vitro. In this test, the $\mathrm{IC}_{50}$ values obtained from baicalein of $0.25 \mathrm{mg} / \mathrm{mL}$ was obtained by a linear equation as the data in Table 12. The difference results obtained presumably because testing procedures are different from previous stud-

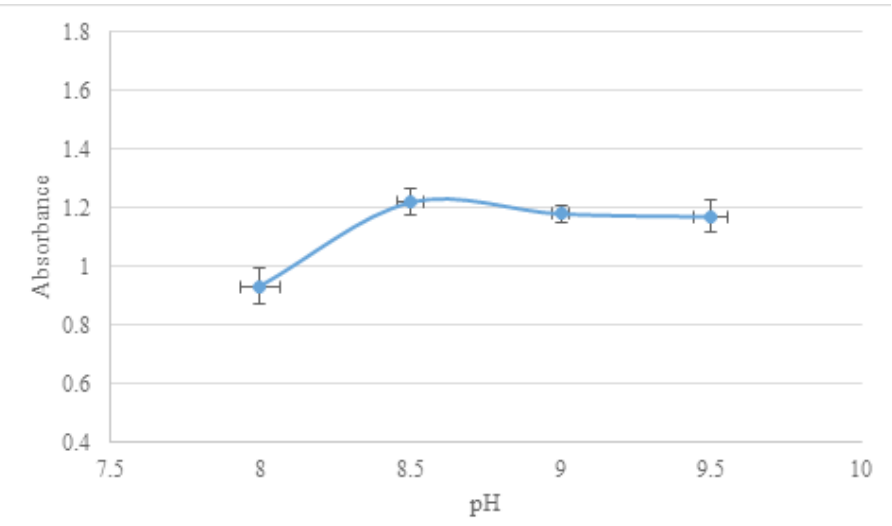

Figure 1: Curve relationship borate buffer $\mathrm{pH} 0.2 \mathrm{M}$ with the uptake.

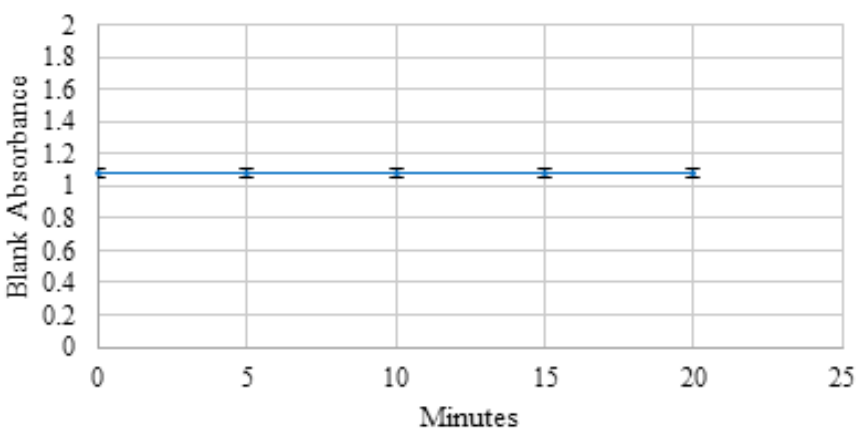

Figure 2: Curve relationship downtime solution stop the uptake. ies because in this study the optimization tests were used to generate maximum data.

\section{Inhibition of Lipoxygenase Activity Assay of Methanol, Ethyl Acetate, and N-Hexane G. porrecta Laness. Stem Bark Extract}

Based on inhibition of lipoxygenase activity assay that has been made to extract methanol, ethyl acetate, and n-hexane bark G. porrecta Laness. $\mathrm{IC}_{50}$ values obtained successively by $0.23 \mathrm{ug} / \mathrm{ml} ; 0.52 \mathrm{ug} / \mathrm{ml}$; and 4.87 ug / $\mathrm{ml}$, can be seen in Table 13 to 15 . The test results showed that the extract has the most active inhibition of lipoxygenase activity is methanol extract. When compared with the positive control baicalein which reaches $50 \%$ inhibition at a concentration of $0.25 \mathrm{mg} / \mathrm{mL}$, then either extract ethyl acetate and n-hexane from the bark of G. porrecta Laness. showed inhibition of lipoxygenase activity is lower than baicalein. The methanol extract stem $G$. porrecta Laness. have a better activity than the positive control baicalein in inhibiting lipoxygenase can be seen from the $\mathrm{IC}_{50}$ values at lower concentrations.

The inhibition of lipoxygenase activity is proportional to the concentration of the extract used in the test. The higher the concentration of the extract is used, the higher the lipoxygenase inhibitory activity as well, so that the product of a reaction between the substrate and lipoxygenase in the form of HpODE will decrease. It is characterized by decreasing absorption of the sample minus the control samples to the increased concentration of the extract.

\section{Determination of Total Flavonoids Level of Methanol Extract from G. porrecta Laness. Stem Bark.}

Based on testing by the FRAP method antioxidant activity and inhibition of lipoxygenase activity, it is obtained methanol extract as the most active extract. Towards the methanol extract of the stem bark of G. porrecta Laness. then performed the assay method flavonoid $\mathrm{AlCl}_{3}$ using UV-Vis spectrophotometer. The results of the optimization maximum wavelength show that the greatest uptake is at a wavelength of $435 \mathrm{~nm}$. Therefore, for the assay positive control quercetin and methanol extract of the

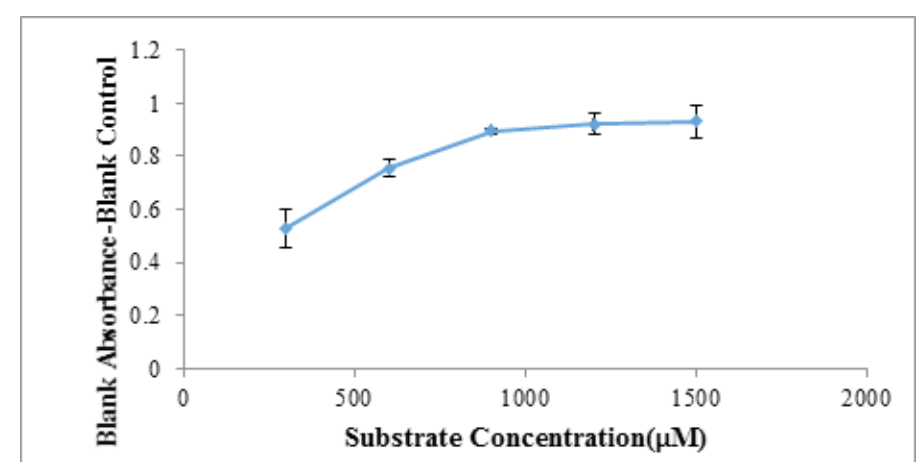

Figure 3: Curve relations substrate concentration by absorbance.

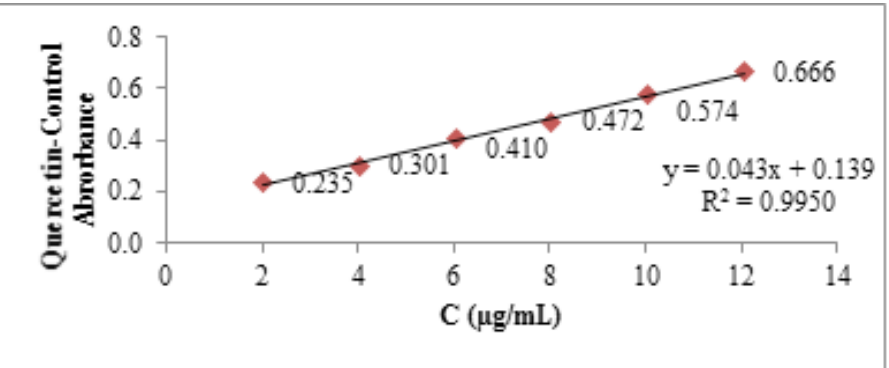

Figure 4: The calibration curve of quercetin. 
Table 1: Composition of the solution to test the antioxidant activity methods FRAP

\begin{tabular}{ccc}
\hline & \multicolumn{2}{c}{ Volume $(\mathrm{mL})$} \\
\cline { 2 - 3 } Material & Standard/Sample & $\begin{array}{c}\text { Control Standard/ } \\
\text { Sample }\end{array}$ \\
\hline Solution FRAP & 3800 & 3800 \\
Baicalein / Extract & 200 & - \\
Ethanol & - & 200 \\
were incubated for 30 minutes at a temperature of $37^{\circ} \mathrm{C}$ and measured \\
absorbance at $595 \mathrm{~nm} \lambda$
\end{tabular}

Table 2: Composition of the mixture on the optimization of $\mathrm{pH}$ buffer solution boric

\begin{tabular}{ccc}
\hline \multirow{2}{*}{ Material } & \multicolumn{2}{c}{ Volume $(\mathrm{mL})$} \\
\cline { 2 - 3 } & Blank & control Blank \\
\hline solution buffer borate $\mathrm{pH} 8,5 ; 9.0 ; 9.5$ & 1700 & 2000 \\
$600 \mu \mathrm{M}$ linoleic acid / $\mathrm{mL}$ & 1000 & 1000 \\
incubated $25^{\circ} \mathrm{C}$ for 10 minutes & - \\
lipoxygenase 10000 units $/ \mathrm{mL}$ & 300 & 1000 \\
incubated $25^{\circ} \mathrm{C}$ for & 15 min \\
stop solution (methanol pro analysis) & 1000 & 4000 \\
Volume end & 4000 & \\
Measured absorbance at $\lambda 234 \mathrm{~nm}$ &
\end{tabular}

Table 3: Composition of the enzyme reaction stopping time optimization of

\begin{tabular}{ccc}
\hline Material & \multicolumn{2}{c}{ Volume $(\mathrm{mL})$} \\
\cline { 2 - 3 } & blank & blank Control \\
\hline $0.2 \mathrm{M}$ borate buffer $\mathrm{pH} 8.5$ & 1700 & 2000 \\
linoleic acid600 $\mu \mathrm{M}$ & 1000 & 1000 \\
were incubated $25^{\circ} \mathrm{C}$ for 10 & minutes \\
lipoxygenase 10000 units $/ \mathrm{mL}$ & 300 & - \\
vortexed then incubation & $25^{\circ} \mathrm{C}$ for $15 \mathrm{~min}$ & 1000 \\
stop solution (methanol pro analysis) & 1000 & 4000 \\
Volume end & 4000 & \\
Measured $\lambda$ absorbance at $234 \mathrm{~nm}$ at time $0 ; 5 ; 10 ; 15$; and 20 minutes
\end{tabular}

Table 4: Composition of the optimization of the concentration of lipoxygenase

\begin{tabular}{ccc}
\hline \multirow{2}{*}{ Material } & \multicolumn{2}{c}{ Volume $(\mathrm{mL})$} \\
\cline { 2 - 3 } & Blank & Blank Control \\
\hline $0.2 \mathrm{M}$ borate buffer $\mathrm{pH} 8.5$ & 1700 & 2000 \\
$600 \mu \mathrm{M}$ linoleic acid / $\mathrm{mL}$ & 1000 & 1000 \\
incubated $25^{\circ} \mathrm{C}$ for 10 minutes & - \\
lipoxygenase (2500; $5000 ; 7500$ and 10000 & 300 & \\
units / $\mathrm{mL})$ & & 1000 \\
incubated $25^{\circ} \mathrm{C}$ for $15 \mathrm{~min}$ & 4000 \\
the solution stop (methanol pro analysis) & 1000 \\
Volume end & 4000 & \\
Measured absorbance at $\lambda 234 \mathrm{~nm}$ &
\end{tabular}

Table 5: Composition of mix optimization the concentration of linoleic acid substrate

\begin{tabular}{ccc|}
\hline \multirow{2}{*}{ Material } & \multicolumn{2}{c}{ Volume $(\mathrm{mL})$} \\
\cline { 2 - 3 } & blank & blank Control \\
\hline $0.2 \mathrm{M}$ borate buffer $\mathrm{pH} 8.5$ & 1700 & 2000 \\
linoleic acid (300; 600; 900; 1200 and 1500 & 1000 & 1000 \\
$\mu \mathrm{M} / \mathrm{mL})$ & & - \\
incubated $25^{\circ} \mathrm{C}$ for 10 minutes & \\
lipoxygenase 10000 units $/ \mathrm{mL}$ & 300 & 1000 \\
vortexed then incubation in $25^{\circ} \mathrm{C}$ for $15 \mathrm{~min}$ & 4000 \\
the solution stop (methanol pro analysis) & 1000 \\
Volume end & 4000 & \\
Measured absorbance at $\lambda 234 \mathrm{~nm}$ &
\end{tabular}

Table 6: Composition of the lipoxygenase inhibition test by baicalein or extract

\begin{tabular}{|c|c|c|c|c|}
\hline \multirow[b]{2}{*}{ Material } & \multicolumn{4}{|c|}{ Volume (mL) } \\
\hline & Blank & $\begin{array}{l}\text { Blank } \\
\text { Control }\end{array}$ & $\begin{array}{l}\text { Standard } \\
\text { /Sample }\end{array}$ & $\begin{array}{c}\text { Standard } \\
\text { Control/ } \\
\text { Sample }\end{array}$ \\
\hline $\begin{array}{c}0.2 \mathrm{M} \text { borate buffer } \mathrm{pH} \\
8.5\end{array}$ & in 1700 & \multirow[t]{2}{*}{16901990} & & 2000 \\
\hline solution baicalein / extract & - & & 10 & 10 \\
\hline linoleic acid $900 \mu \mathrm{M} / \mathrm{mL}$ & to 1000 & 1000 & 1000 & 1000 \\
\hline \multicolumn{5}{|c|}{ was incubated $25^{\circ} \mathrm{C}$ for 10 minutes } \\
\hline $\begin{array}{l}\text { lipoxygenase } 10000 \text { units } \\
\qquad / \mathrm{mL}\end{array}$ & & & $300-300$ & - \\
\hline \multicolumn{5}{|c|}{ vortexed then incubate $25^{\circ} \mathrm{C}$ for 5 minutes } \\
\hline $\begin{array}{l}\text { solution stop (Methanol } \\
\text { pro analysis) }\end{array}$ & $\begin{array}{l}1000 \\
1000 \\
1000\end{array}$ & & & 1000 \\
\hline Volume end & $\begin{array}{l}4000 \\
4000 \\
4000\end{array}$ & & & 4000 \\
\hline \multicolumn{5}{|c|}{ Measured by absorbance at $234 \mathrm{~nm} \lambda$} \\
\hline
\end{tabular}

bark of $G$. porrecta Laness. use a maximum wavelength of $435 \mathrm{~nm}$. In testing the use of quercetin as a positive control and quercetin calibration curve was made to determine the linear regression equation. The linear regression equation of quercetin obtained value of $0,0431 x+y=0.1394$. By testing methanol extract $6012 \mathrm{mg} / \mathrm{mL}$, absorption generated after deducting the control sample of 0.286 . Based on calculations using the linear regression equation quercetin, obtained value $\mathrm{x}$ (extract concentration) of $3.40 \mathrm{mg} / \mathrm{mL}$. Levels of total flavonoids calculated using equivalent levels of quercetin and obtained flavonoid (quercetin equivalents / g) of $5.66 \mathrm{mgQE} / \mathrm{g}$. From the results obtained, the levels of flavonoids in the methanol extract of the bark of Garcinia porrecta Laness which have antioxidant activity and inhibition of lipoxygenase enzymes highest is only $0.56 \%$. Suspected of secondary metabolites such as group xanthones, ${ }^{10}$ triterpene and phloroglucinol provide a synergistic effect with compounds flavonoids in antioxidant activity and inhibition of enzyme lipoxygenase. ${ }^{9}$ 
Table 7: Table of data values $\mathrm{EC}_{50}$ baicalein on tests of antioxidant activity methods FRAP

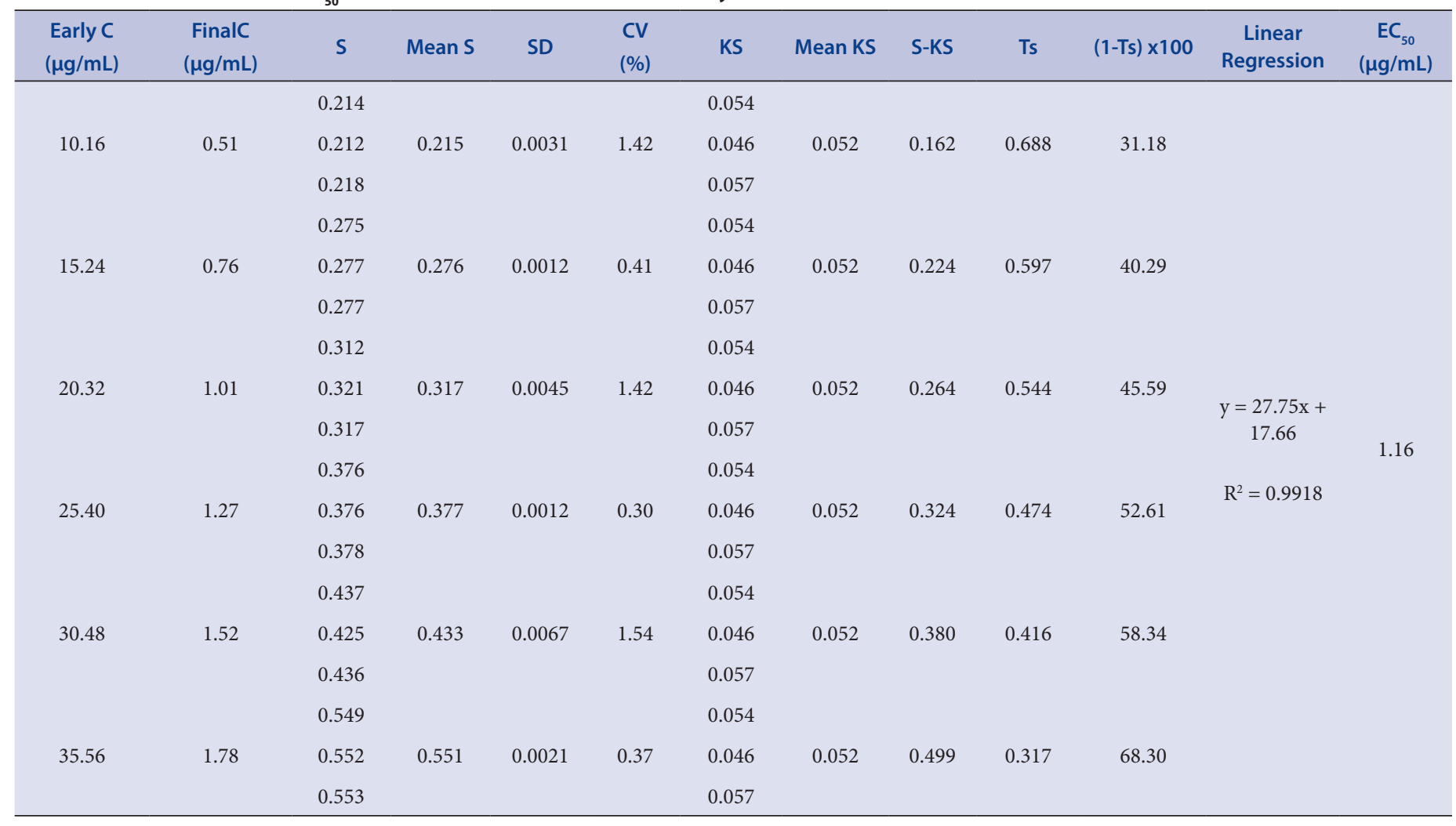

$\mathrm{C}=$ Concentration; $\mathrm{S}=$ Baicalein Absorbance; $\mathrm{KS}=$ Control Baicalein Absorbance; $\mathrm{Ts}=$ Transmittant

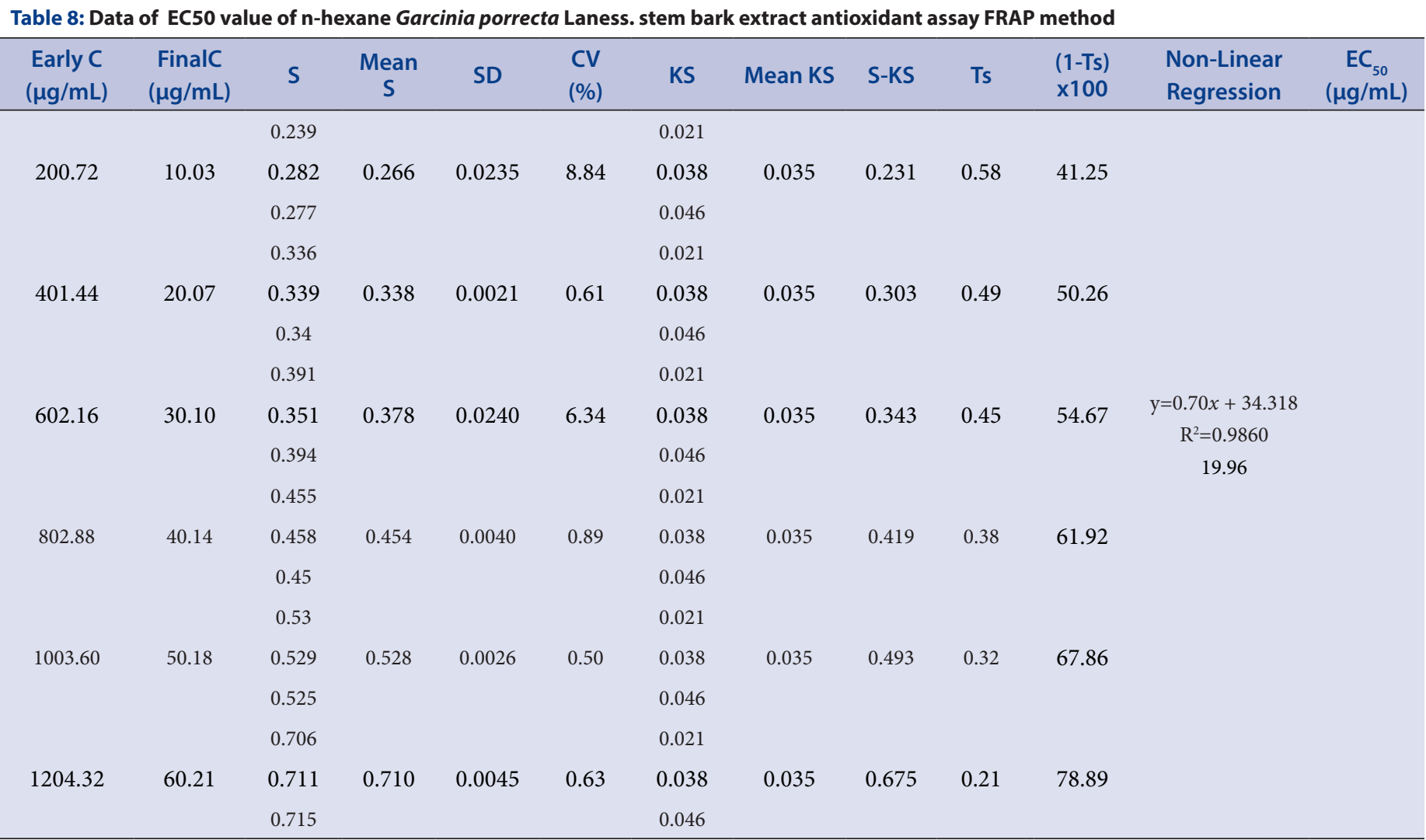

C = Concentration; $\mathrm{S}=$ Baicalein Absorbance; $\mathrm{KS}$ = Control Baicalein Absorbance; Ts = Transmittant 


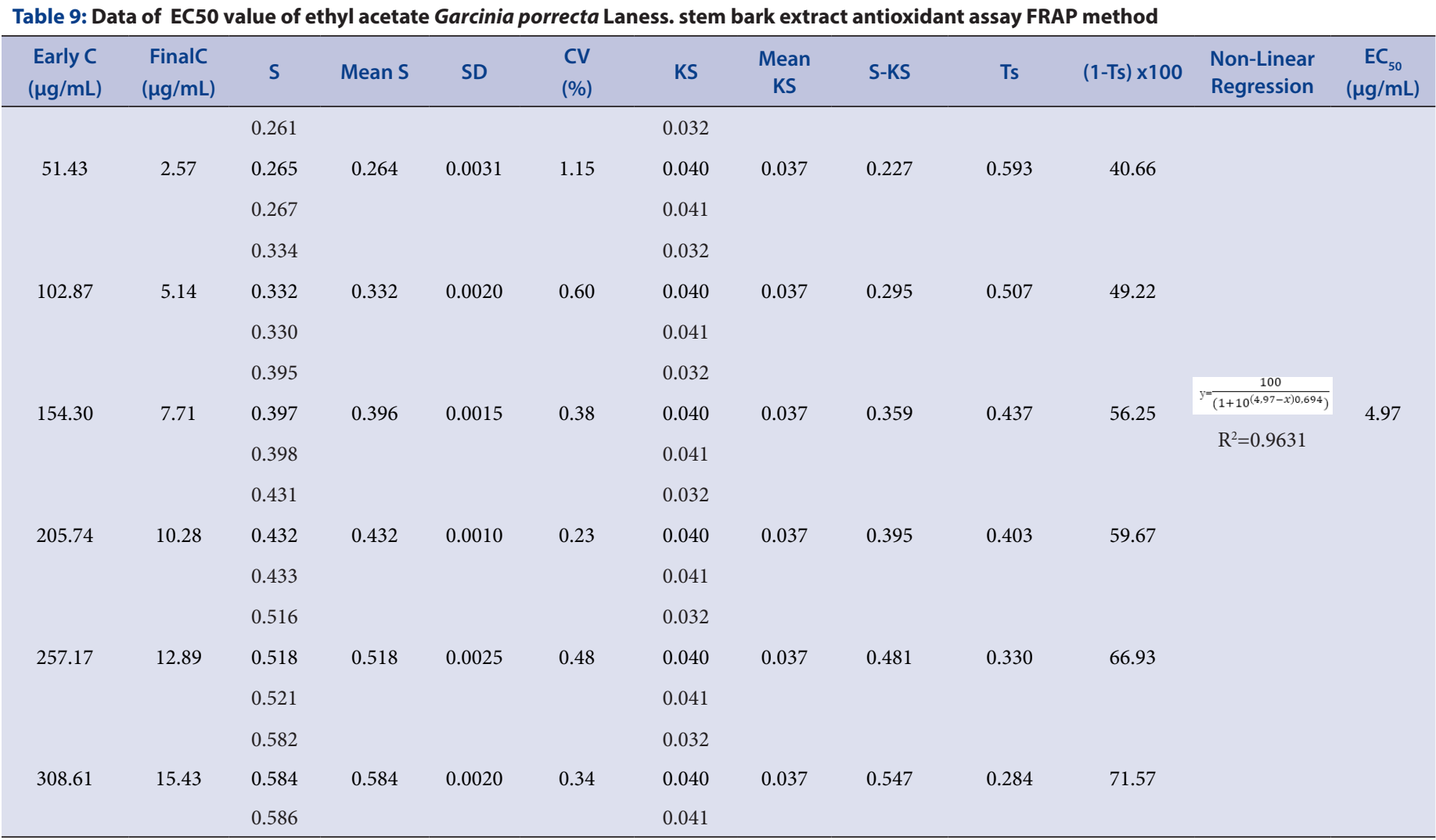

$\mathrm{C}=$ Concentration; $\mathrm{S}=$ Baicalein Absorbance; $\mathrm{KS}=$ Control Baicalein Absorbance; $\mathrm{Ts}=$ Transmittant

Table 10: Data of $\mathrm{EC}_{50}$ value of methanol Garcinia porrecta Laness. stem bark extract antioxidant assay FRAP method

\begin{tabular}{|c|c|c|c|c|c|c|c|c|c|c|c|c|}
\hline $\begin{array}{c}\text { Early C } \\
(\mu \mathrm{g} / \mathrm{mL})\end{array}$ & $\begin{array}{c}\text { FinalC } \\
(\mu \mathrm{g} / \mathrm{mL})\end{array}$ & $S$ & Mean S & SD & $\begin{array}{l}\text { CV } \\
(\%)\end{array}$ & KS & $\begin{array}{c}\text { Mean } \\
\text { KS }\end{array}$ & S-KS & Ts & $\begin{array}{l}\text { (1-Ts) } \\
\times 100\end{array}$ & $\begin{array}{l}\text { Non-Linear } \\
\text { Regression }\end{array}$ & $\begin{array}{c}E_{50} \\
(\mu \mathrm{g} / \mathrm{mL})\end{array}$ \\
\hline & & 0.223 & & & & 0.021 & & & & & & \\
\hline \multirow[t]{3}{*}{10.01} & 0.50 & 0.225 & 0,224 & 0.0015 & 0.68 & 0.046 & 0.035 & 0.189 & 0.64 & 35.33 & & \\
\hline & & 0.226 & & & & 0.039 & & & & & & \\
\hline & & 0.270 & & & & 0.021 & & & & & & \\
\hline \multirow[t]{3}{*}{20.03} & 1.00 & 0.272 & 0.272 & 0.0020 & 0.73 & 0.046 & 0.035 & 0.236 & 0.58 & 42.01 & $y=\frac{100}{\left(1+10^{(0,12-x) 0,728)}\right.}$ & \\
\hline & & 0.274 & & & & 0.039 & & & & & & \\
\hline & & 0.349 & & & & 0.021 & & & & & & \\
\hline \multirow[t]{3}{*}{30.04} & 1.50 & 0.350 & 0.352 & 0.0049 & 1.40 & 0.046 & 0.035 & 0.317 & 0.48 & 51.80 & $\mathrm{R}^{2}=0.9639$ & 1.33 \\
\hline & & 0.358 & & & & 0.039 & & & & & & \\
\hline & & 0.403 & & & & 0.021 & & & & & & \\
\hline \multirow[t]{3}{*}{40.05} & 2.00 & 0.399 & 0.4023 & 0.0031 & 0.76 & 0.046 & 0.035 & 0.367 & 0.43 & 57.04 & & \\
\hline & & 0.405 & & & & 0.039 & & & & & & \\
\hline & & 0.439 & & & & 0.021 & & & & & & \\
\hline \multirow[t]{3}{*}{50.07} & 2.50 & 0.441 & 0.432 & 0.0127 & 2.94 & 0.046 & 0.035 & 0.397 & 0.40 & 59.94 & & \\
\hline & & 0.418 & & & & 0.039 & & & & & & \\
\hline & & 0.524 & & & & 0.021 & & & & & & \\
\hline \multirow[t]{2}{*}{60.08} & 3.00 & 0.526 & 0.523 & 0.0031 & 0.58 & 0.046 & 0.035 & 0.488 & 0.32 & 67.49 & & \\
\hline & & 0.520 & & & & 0.039 & & & & & & \\
\hline
\end{tabular}

$\mathrm{C}=$ Concentration; $\mathrm{S}=$ Baicalein Absorbance; $\mathrm{KS}=$ Control Baicalein Absorbance; $\mathrm{Ts}=$ Transmittant 


\begin{tabular}{|c|c|c|c|c|c|c|}
\hline $\begin{array}{l}\text { the concentration of the } \\
\text { enzyme } \\
\text { (units } / \mathrm{mL} \text { ) }\end{array}$ & $\begin{array}{l}\text { Uptake } \\
\text { Blank } \\
\text { (a) }\end{array}$ & $\begin{array}{c}\text { Average } \\
\text { Uptake blank } \\
\text { (a) }\end{array}$ & SD & $\begin{array}{l}\text { CV } \\
(\%)\end{array}$ & $\begin{array}{l}\text { Uptake } \\
\text { control } \\
\text { Blanko } \\
\text { (b) }\end{array}$ & $a-b$ \\
\hline 2500 & $\begin{array}{l}0.773 \\
0.786 \\
0.910\end{array}$ & 0.823 & 0.0756 & 9.19 & 0.471 & 0.352 \\
\hline 5000 & $\begin{array}{l}1.243 \\
1.247 \\
1.184\end{array}$ & 1.225 & 0.0353 & 2.88 & 0.474 & 0.751 \\
\hline 7500 & $\begin{array}{l}1.333 \\
1.389 \\
1.301\end{array}$ & 1.341 & 0.0445 & 3.32 & 0.471 & 0.870 \\
\hline 10000 & $\begin{array}{l}1.687 \\
1.740 \\
1.591\end{array}$ & 1.673 & 0.0755 & 4.51 & 0.471 & 1.202 \\
\hline
\end{tabular}

Table 12: Table of data values IC50 baicalein at lipoxygenase inhibition activity test

\begin{tabular}{|c|c|c|c|c|c|c|c|c|c|c|c|c|c|c|}
\hline $\begin{array}{l}\text { B } \\
\text { (a) }\end{array}$ & $\begin{array}{l}K B \\
\text { (b) }\end{array}$ & $\begin{array}{l}\text { B-KB } \\
(a b)\end{array}$ & $\begin{array}{c}\text { mean } \\
\text { B-KB }\end{array}$ & $\begin{array}{c}\text { C early } \\
\text { (ug / } \\
\mathrm{mL} \text { ) }\end{array}$ & $\begin{array}{c}\text { C final } \\
\text { (ug / } \\
\mathrm{mL} \text { ) }\end{array}$ & $S$ & $\begin{array}{c}\text { mean } \\
\mathrm{S} \\
\text { (c) }\end{array}$ & SD & $\begin{array}{l}\text { CV } \\
(\%)\end{array}$ & $\begin{array}{l}\text { KS } \\
\text { (d) }\end{array}$ & $\begin{array}{l}\text { S-KS } \\
\text { (cd)\% }\end{array}$ & Inhibition & $\begin{array}{l}\text { Linear } \\
\text { Regression }\end{array}$ & $\begin{array}{c}\mathrm{IC}_{50} \\
\text { (ug } / \mathrm{ml})\end{array}$ \\
\hline \multirow{6}{*}{1.793} & \multirow{6}{*}{0.491} & \multirow{6}{*}{1.302} & & & & 2.145 & & & & & & & \multirow{6}{*}{$y=176.7 x$} & \multirow{16}{*}{0.25} \\
\hline & & & & 41.6 & 0.104 & 2.140 & 2.160 & 0.0304 & 1.40 & 1.174 & 0.986 & 23.90 & & \\
\hline & & & & & & 2.195 & & & & & & & & \\
\hline & & & & & & 2.076 & & & & & & & & \\
\hline & & & & 52.0 & 0.130 & 2.050 & 2.033 & 0.0530 & 2.60 & 1.119 & 0.914 & 29.43 & & \\
\hline & & & & & & 1.974 & & & & & & & & \\
\hline \multirow{5}{*}{1.788} & \multirow{5}{*}{0.497} & \multirow{5}{*}{1.291} & \multirow{5}{*}{1.296} & 624 & 0156 & 1.990 & 2000 & 00215 & 107 & 1150 & 0850 & 3437 & +5.799 & \\
\hline & & & & & & 1.986 & & \multirow{4}{*}{0.0405} & \multirow{4}{*}{2.13} & \multirow{4}{*}{1.093} & \multirow{4}{*}{0.808} & \multirow{4}{*}{37.66} & \multirow{4}{*}{$\mathrm{R}^{2}=0.9910$} & \\
\hline & & & & \multirow{3}{*}{72.8} & \multirow{3}{*}{0.182} & 1.868 & \multirow{3}{*}{1.901} & & & & & & & \\
\hline & & & & & & 1.888 & & & & & & & & \\
\hline & & & & & & 1.946 & & & & & & & & \\
\hline \multirow{6}{*}{1.794} & \multirow{6}{*}{0.500} & \multirow{6}{*}{1.294} & & \multirow{4}{*}{83.2} & \multirow{4}{*}{0.208} & 1.886 & \multirow{3}{*}{1.900} & \multirow{3}{*}{0.0365} & \multirow{3}{*}{1.92} & \multirow{3}{*}{1.131} & \multirow{3}{*}{0.769} & \multirow{3}{*}{40.67} & & \\
\hline & & & & & & 1.941 & & & & & & & & \\
\hline & & & & & & 1.872 & & & & & & & & \\
\hline & & & & & & 1.526 & \multirow{3}{*}{1.502} & & & & & & & \\
\hline & & & & \multirow[t]{2}{*}{114.4} & \multirow[t]{2}{*}{0.286} & 1.473 & & 0.0268 & 1.78 & 0.947 & 0.555 & 57.19 & & \\
\hline & & & & & & 1.506 & & & & & & & & \\
\hline
\end{tabular}

$\mathrm{B}=$ blank; $\mathrm{KB}=$ bank control $\mathrm{C}=$ concentration; $\mathrm{S}$ = baicalein absorbance; $\mathrm{KS}=$ baicalein control absorbance 
Table 13: Table of data values $I_{50} n$-hexane extract at lipoxygenase inhibition activity test

\begin{tabular}{|c|c|c|c|c|c|c|c|c|c|c|c|c|c|c|}
\hline B & KB & B-KB & C early & C final & 5 & mean $\mathrm{S}$ & SD & $\mathrm{CV}$ & KS & $\begin{array}{c}\text { mean } \\
\text { KS }\end{array}$ & S-KS & $\%$ inhibition & Non-Linear & IC50 \\
\hline (a) & (b) & $(a-b)$ & $(\mu \mathrm{g} / \mathrm{mL})$ & $(\mu \mathrm{g} / \mathrm{mL})$ & & (c) & & (\%) & & (d) & (c-d) & & & $(\mu \mathrm{g} / \mathrm{mL})$ \\
\hline \multirow{18}{*}{1.528} & \multirow{18}{*}{0.731} & \multirow{18}{*}{0.797} & \multirow{3}{*}{1505.4} & \multirow{3}{*}{3.76} & 1.068 & \multirow{3}{*}{1.058} & \multirow{3}{*}{0.0507} & \multirow{3}{*}{4.79} & 0.684 & \multirow{3}{*}{0.684} & \multirow{3}{*}{0.374} & \multirow{3}{*}{46.99} & & \multirow{17}{*}{4.87} \\
\hline & & & & & 1.004 & & & & 0.684 & & & & & \\
\hline & & & & & 1.105 & & & & 0.684 & & & & & \\
\hline & & & \multirow{3}{*}{2007.2} & \multirow{3}{*}{5.02} & 0.986 & \multirow{3}{*}{1.002} & \multirow{3}{*}{0.0144} & \multirow{3}{*}{1.44} & 0.605 & \multirow{3}{*}{0.605} & \multirow{3}{*}{0.397} & \multirow{3}{*}{49.89} & & \\
\hline & & & & & 1.011 & & & & 0.605 & & & & & \\
\hline & & & & & 1.011 & & & & 0.605 & & & & & \\
\hline & & & \multirow{3}{*}{2509} & \multirow{3}{*}{6.27} & 1.059 & \multirow{3}{*}{1.109} & \multirow{3}{*}{0.0676} & \multirow{3}{*}{6.09} & 0.689 & \multirow{3}{*}{0.689} & \multirow{3}{*}{0.420} & \multirow{3}{*}{52.75} & 100 & \\
\hline & & & & & 1.186 & & & & 0.689 & & & & $=\left(1+10^{(0,68-x) 0,629)}\right.$ & \\
\hline & & & & & 1.083 & & & & 0.689 & & & & $\mathrm{R}^{2}=0.9766$ & \\
\hline & & & \multirow{3}{*}{3010.8} & \multirow{3}{*}{7.52} & 1.148 & \multirow{3}{*}{1.144} & \multirow{3}{*}{0.0035} & & 0.694 & & & & & \\
\hline & & & & & 1.141 & & & 0.30 & 0.694 & 0.694 & 0.450 & 56.54 & & \\
\hline & & & & & 1.145 & & & & 0.694 & & & & & \\
\hline & & & & & 1.168 & & & & 0.692 & & & & & \\
\hline & & & 3512.6 & 8.78 & 1.165 & 1.163 & 0.0051 & 0.44 & 0.692 & 0.691 & 0.472 & 59.24 & & \\
\hline & & & & & 1.158 & & & & 0.692 & & & & & \\
\hline & & & & & 1.207 & & & & 0.726 & & & & & \\
\hline & & & 4014.4 & 10.03 & 1.221 & 1.221 & 0.0145 & 1.18 & 0.726 & 0.726 & 0.495 & 62.11 & & \\
\hline & & & & & 1.236 & & & & 0.726 & & & & & \\
\hline
\end{tabular}

$\mathrm{B}=$ blank; $\mathrm{KB}=$ bank control $\mathrm{C}$ = concentration; $\mathrm{S}=$ baicalein absorbance; $\mathrm{KS}$ = baicalein control absorbance

Table 14: Table of data values $I_{50}$ ethyl acetate extract at lipoxygenase inhibition activity test

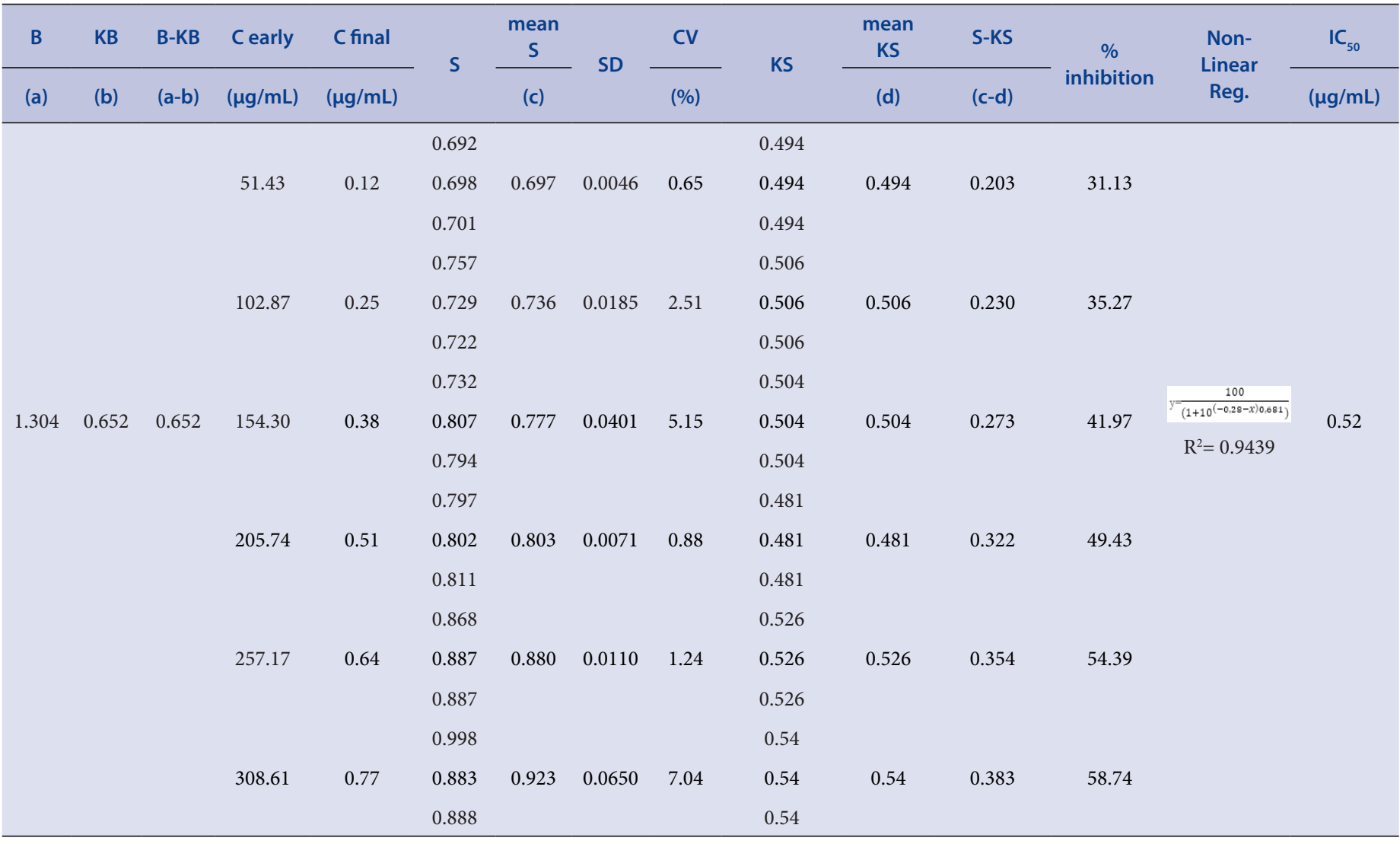

$\mathrm{B}=$ blank; $\mathrm{KB}=$ bank control; $\mathrm{C}=$ concentration; $\mathrm{S}$ = baicalein absorbance; $\mathrm{KS}$ = baicalein control absorbance 
Table 15: Table of data values $I_{50}$ methanol extract at lipoxygenase inhibition activity test

\begin{tabular}{|c|c|c|c|c|c|c|c|c|c|c|c|c|c|c|}
\hline B & KB & B-KB & C early & C final & \multirow{2}{*}{$S$} & mean S & \multirow{2}{*}{ SD } & CV & \multirow{2}{*}{ KS } & $\begin{array}{c}\text { mean } \\
\text { KS }\end{array}$ & S-KS & \multirow{2}{*}{$\begin{array}{c}\% \\
\text { inhibition }\end{array}$} & \multirow{2}{*}{$\begin{array}{l}\text { Non-Linear } \\
\text { Reg. }\end{array}$} & \multirow{2}{*}{$\begin{array}{l}\mathrm{IC}_{50} \\
(\mu \mathrm{g} / \\
\mathrm{mL})\end{array}$} \\
\hline (a) & (b) & $(a-b)$ & $(\mu \mathrm{g} / \mathrm{mL})$ & $\begin{array}{l}(\mu \mathrm{g} / \\
\mathrm{mL})\end{array}$ & & (c) & & (\%) & & (d) & (c-d) & & & \\
\hline & & & & & 0.632 & & & & 0.465 & & & & & \\
\hline & & & 50.07 & 0.12 & 0.636 & 0.638 & 0.0077 & 1.21 & 0.465 & 0.465 & 0.173 & 37.84 & & \\
\hline & & & & & 0.647 & & & & 0.465 & & & & & \\
\hline & & & & & 0.525 & & & & 0.289 & & & & & \\
\hline & & & 100.14 & 0.25 & 0.521 & 0.508 & 0.0260 & 5.13 & 0.289 & 0.289 & 0.219 & 47.81 & & \\
\hline & & & & & 0.478 & & & & 0.289 & & & & & \\
\hline & & & & & 1.080 & & & & 0.769 & & & & & \\
\hline \multirow[t]{11}{*}{0.847} & 0.389 & 0.458 & 150.21 & 0.37 & 1.001 & 1.030 & 0.0434 & 4.22 & 0.769 & 0.769 & 0.261 & 56.99 & 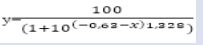 & 0.23 \\
\hline & & & & & 1.009 & & & & 0.769 & & & & $\mathrm{R}^{2}=0.9944$ & \\
\hline & & & & & 0.714 & & & & 0.394 & & & & & \\
\hline & & & 200.28 & 0.50 & 0.727 & 0.727 & 0.0140 & 1.92 & 0.394 & 0.394 & 0.333 & 72.85 & & \\
\hline & & & & & 0.742 & & & & 0.394 & & & & & \\
\hline & & & & & 1.104 & & & & 0.761 & & & & & \\
\hline & & & 250.35 & 0.62 & 1.115 & 1.133 & 0.0422 & 3.72 & 0.761 & 0.761 & 0.372 & 81.36 & & \\
\hline & & & & & 1.182 & & & & 0.761 & & & & & \\
\hline & & & & & 1.019 & & & & 0.618 & & & & & \\
\hline & & & 300.42 & 0.75 & 1.057 & 1.043 & 0.0213 & 2.05 & 0.618 & 0.618 & 0.425 & 92.94 & & \\
\hline & & & & & 1.055 & & & & 0.618 & & & & & \\
\hline
\end{tabular}

$\mathrm{B}=$ blank; $\mathrm{KB}=$ bank control; $\mathrm{C}$ = concentration; $\mathrm{S}$ = baicalein absorbance; $\mathrm{KS}$ = baicalein control absorbance

\section{CONCLUSION}

Based on the results of testing that has been done to extract methanol, ethyl acetate and n-hexane bark of Garcinia porrecta Laness., can be summed up as follows.

extracts of methanol, ethyl acetate and n-hexane bark of Garcinia porrecta Laness. have antioxidant activity with ECvalues $_{50}$ of 1.33 respectively; 4.97; and $19.96 \mathrm{ug} / \mathrm{ml}$. Extracts with activity are the most active extract of methanol.

The methanol extract, ethyl acetate and n-hexane bark of Garcinia porrecta Laness. has the lipoxygenase inhibitory activity with ICvalues $_{50}$ of 0.23 respectively; 0.52 ; and $4.87 \mathrm{mg} / \mathrm{mL}$. Extracts with an activity of the most active are methanol extract.

Levels of total flavonoids of the most active extracts, namely methanol extract are equal to $5.66 \mathrm{mg} \mathrm{QE} / \mathrm{g}$ (quercetin equivalent).

\section{ACKNOWLEDGEMENT}

Thanks to PITTA Grant University of Indonesia that funding this research.

\section{CONFLICT OF INTEREST}

None

\section{ABBREVIATION USED}

\section{REFERENCES}

1. Handajani A, Roosihermiatie B, Maryani H. Faktor-faktor yang Berhubungan dengan Pola Kematian pada Penyakit Degeneratif di Indonesia. Bulletin Peneli- tian Sistem Kesehatan. 2010:13(1):42-53.

2. Valko M, Leibfritz D, Moncol J, Cronin MT, Mazur M, Telser J. Free radicals and antioxidants in normal physiological functions and human disease. International Journal of Biochemistry Cell. 2007;39(1357-2725(Print)):44-84.

3. Jung HA, Ning SBao, Keller WJ, Mehta RG, Kinghorn AD. Antioxidant Xanthones from the Pericarp of Garcinia mangostana (mangosteen). Journal of Agricultural and Food Chemistry. 2006;54.

4. Corwin E J. Handbook of Pathophysiology (3rd Edition). Philadelphia: Lippincott Williams \& Wilkins. 2008.

5. Kumar V, Bhat ZA, Kumar D, Khan NA, Chashoo IA. Evaluation of anti-inflammatory potential of leaf extracts of Skimmia anquetilia. Asian Pacific Journal of Tropical Biomedicine. 2012;2(8):627-30.

6. Roussaki et al. Bioorganic \& Medicinal Chemistry Structural modifications of coumarin derivatives : Determination of antioxidant and lipoxygenase (LOX) inhibitory activity. Bioorganic and Medicinal Chemistry. 2014;22(23):6586-94.

7. Murray RK, Granner DK, Rodwell WW. Biokimia Harper Edisi 27. Jakarta: EGC Penerbit Buku Kedokteran. 2006

8. Deschamps JD, Kenyon VA, Holman TR. Baicalein is potent in vitro inhibitor against both reticulocyte 15-human and platelet 12-human lipoxygenases. Bioorganic and Medicinal Chemistry. 2006;14(12):4295-301.

9. Ritthiwigrom T, Laphookhieo S, Pyne SG. Chemical constituents and biological activities of Garcinia cowa Roxb. Maejo International Journal Od Science Ang Technology. 2013;7(2):212-31.

10. Kardono LBS, Hanafi M, Sherley G, Kosela S, Harrison LJ. Bioactive Constituent of Garcinia porrecta and G. parvifolia Grown Ni Indonesia. Pakistan Journal of Biological Sciences. 2006;9(3):483-6.

11. Fidrianny I, Aristya T, Hartati R. Antioxidant Capacities of Various Leaves Extracts from Three Species of Legumes and Correlation with Total Flavonoid, Phenolic, Carotenoid Content. International Journal of Pharmacognosy And Phytochemical Research. 2015;7(3):628-34.

12. Abdullah AR, Bakhari NA, Osman H. Study on the Relationship of the Phenolic Flavonoids, and Tannin Content to the Antioxidant Activity of Garcinia atroviridis. University Journal of Applied Science. 2013;1(3):95-100.

13. Schomburg I, Schomburg D. Class 1 Oxidoreductases X_EC 1. In Springer Handbook of Enzyme, Vol 25, Second Edition (Second Ed., pp. 593-595). Berlin: Springer. 2007 


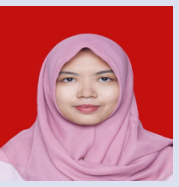

\section{ABOUT AUTHORS}

Amalia Cipta Sari Undergraduate Student from Faculty of Pharmacy, University of Indonesia. Enrolling Apothecary Program in Faculty of Pharmacy University of Indonesia.

Elya: Lecturer, Researcher, and Laboratory of Phytochemistry and Pharmacognos, Faculty of Pharmacy, University of Indonesia.

Katrin: Lecturer, Researcher, and Laboratory of Phytochemistry and Pharmacognos, Faculty of Pharmacy, University of Indonesia

Cite this Article: Sari AC, Elya B, Katrin. Antioxidant Activity and Lipoxygenase Enzyme Inhibition Assay with Total Flavonoid Assay of Garcinia porrecta Laness. Stem Bark Extracts. Pharmacognosy Journal, 2017;9(2):257-66. 